\title{
Review Article \\ Comparison of In Vitro and In Situ Methods for Studying Lipolysis
}

\author{
Ahmad Ghorbani ${ }^{1}$ and Mahmood Abedinzade ${ }^{2}$ \\ ${ }^{1}$ Pharmacological Research Center of Medicinal Plants, School of Medicine, Mashhad University of Medical Sciences, \\ Mashhad 9177948564, Iran \\ ${ }^{2}$ Paramedical School of Langeroud, Guilan University of Medical Sciences, Langeroud 4193844937, Iran
}

Correspondence should be addressed to Ahmad Ghorbani; ghorbania@mums.ac.ir

Received 20 May 2013; Accepted 21 July 2013

Academic Editors: C. Fürnsinn, T. Kalamatianos, and C. G. Scanes

Copyright (C) 2013 A. Ghorbani and M. Abedinzade. This is an open access article distributed under the Creative Commons Attribution License, which permits unrestricted use, distribution, and reproduction in any medium, provided the original work is properly cited.

\begin{abstract}
Lipolysis is a highly regulated process and is controlled by nervous system, hormones, and paracrine/autocrine factors. Dysregulation of lipolysis is associated with some pathophysiological conditions including diabetes, metabolic syndrome, and obesity. Nowadays, special attention istherefore paid to study lipolysis using different experimental models. This review summarizes the current experimental methods for studying lipolysis. Culture of preadipocyte cell lines, use of differentiated stroma-vascular cells, primary culture of adipocyte, organ culture of adipose tissue, and microdialysis technique are the most widely used techniques to study lipolysis. The advantages and limitations of using these methods are discussed.
\end{abstract}

\section{Introduction}

Adipose tissue is one of the largest body compartments with various physiological roles including lipid handling and hormone secretion. It is responsible for the storage of fat as triglyceride (via lipogenesis) during times of energy excess and for the mobilization of triglyceride (via lipolysis) during periods of calories deficit [1]. Hormone-sensitive lipase, a rate-limiting enzyme, and monoglyceride lipase catalyse hydrolysis of triglyceride to release fatty acids and glycerol. Unlike fatty acids, glycerol is not reutilized by adipocytes because these cells contain very little glycerol kinase [2]. Therefore, measurement of glycerol gives a good estimate for level of lipolysis [3]. Lipolysis is a highly regulated process and is disciplined by nervous system, hormones (e.g., insulin and catecholamines), and paracrine/autocrine factors (e.g., adenosine, prostaglandins, nitric oxide, and TNF- $\alpha$ ) $[1,3-5]$. Physical activity, nutrition, gender, age and genetic are also important determinant factors for lipolysis $[2,4]$.

Dysregulation of lipolysis is associated with a number of pathophysiological conditions such as obesity, diabetes, metabolic syndrome, familial combined hyperlipidaemia, and polycystic ovarian syndrome [4]. Nowadays, special attention is therefore paid to study lipolysis and other aspects of adipose tissue metabolism. While isotopic tracer techniques and arteriovenous difference method allow in vivo estimation of lipolysis, culture of preadipocyte cell lines, primary culture of adipocyte, organ culture of adipose tissue, and microdialysis are of the most used techniques for studying lipolysis in vitro and in situ. This review summarizes the in vitro and in situ techniques for studying lipolysis in animal and humans. Moreover, the advantages and drawbacks of using each method are discussed (Table 1).

\section{Experimental Methods}

2.1. Culture of Preadipocyte Cell Lines. There are several murine and human preadipocyte cell lines for studying adipocyte metabolism, for example, 3T3-L1, 3T3-F422A, LS14, LiSa-2, and HPB-AML-I [6-9]. Among them, 3T3L1 cells are best characterized and widely used in lipogenesis and lipolysis research for over 30 years. Originally, the cells were isolated from Swiss 3T3 mouse embryos by Green and Kehinde [6]. Preadipocyte cell lines have fibroblast-like morphology. However, when they enter, a confluent stage undergoes a differentiation to an adipocyte-like 
TABLE 1: Advantages and limitations of some experimental methods for studying lipolysis.

\begin{tabular}{|c|c|c|}
\hline Method & Advantages & Limitations \\
\hline $\begin{array}{l}\text { Culture of preadipocyte } \\
\text { cell lines and } \\
\text { differentiated } \\
\text { stroma-vascular cells }\end{array}$ & $\begin{array}{l}\text { Provides abundant supply of homogeneous cells } \\
\text { Suitable for screening agents for their possible } \\
\text { lipolytic or antilipolytic activities } \\
\text { Appropriate for long-term in vitro studies } \\
\text { Suitable for studying molecular mechanisms and } \\
\text { transcription factors involved in lipolysis process }\end{array}$ & $\begin{array}{l}\text { It takes several days until the cells become ready for } \\
\text { study } \\
\text { The cells may not fully differentiate to adipocytes } \\
\text { Differentiation capacity decreases with increasing } \\
\text { number of passages } \\
\text { Excludes nervous system and endocrine system } \\
\text { effects, therefore results may not fully reflect in vivo } \\
\text { condition } \\
\text { Glycerol reagent should be highly sensitive }\end{array}$ \\
\hline $\begin{array}{l}\text { Primary culture of } \\
\text { adipocyte }\end{array}$ & $\begin{array}{l}\text { Most of isolated adipocytes are fully differentiated } \\
\text { A rapid method for testing acute effect of } \\
\text { compounds } \\
\text { Suitable for screening agents for their possible } \\
\text { lipolytic or antilipolytic activities } \\
\text { Comparative use of adipocytes from different } \\
\text { depots }\end{array}$ & $\begin{array}{l}\text { Need to high } n \text { number to resolve interindividual } \\
\text { variations } \\
\text { Need for enzymatic digestion } \\
\text { Loss of hormone sensitivity and gene expression in } \\
\text { long-term culture } \\
\text { High variability in results obtained from freshly } \\
\text { isolated cells } \\
\text { Excludes nervous system and endocrine system } \\
\text { effects } \\
\text { Glycerol reagent should be highly sensitive }\end{array}$ \\
\hline $\begin{array}{l}\text { Organ culture of adipose } \\
\text { tissue }\end{array}$ & $\begin{array}{l}\text { Preserves extracellular matrix and paracrine } \\
\text { interactions } \\
\text { Good correlation with in vivo studies } \\
\text { Useful for chronic lipolysis studies } \\
\text { Suitable for assessing the long-term regulation of } \\
\text { gen involved in the lipolysis pathways } \\
\text { Comparative use of adipocytes from different } \\
\text { depots }\end{array}$ & $\begin{array}{l}\text { Presence of multiple cell types in tissue complicates } \\
\text { interpretation of molecular mechanisms of tested } \\
\text { drug } \\
\text { Excludes nervous system and endocrine system } \\
\text { effects }\end{array}$ \\
\hline $\begin{array}{l}\text { Microdialysis of adipose } \\
\text { tissue }\end{array}$ & $\begin{array}{l}\text { Preserves extracellular matrix and paracrine } \\
\text { interactions } \\
\text { Preserves nervous system and endocrine system } \\
\text { effects } \\
\text { Enables continuous monitoring of lipolysis } \\
\text { Allows study of adipose tissue response during } \\
\text { systemic drug administration }\end{array}$ & $\begin{array}{l}\text { Its application on human is restricted to } \\
\text { subcutaneous fat depot } \\
\text { It is time consuming and uncomfortable for the } \\
\text { patients }\end{array}$ \\
\hline
\end{tabular}

phenotype by addition of a standard differentiation cocktail containing insulin, dexamethasone, and a nonselective phosphodiesetrase-3 inhibitor [10]. These cells are sensitive to lipolytic (e.g., $\beta$-adrenergic receptor agonists) and antilipolytic (e.g., insulin) agents $[10,11]$. Upon reaching confluence, 3T3-L1 cells start to express markers characteristic of differentiation from day 3 and usually complete the differentiation process by day 8 [10-12]. Therefore, it took more than one week until the cells be ready for lipolysis study. Yet, the cells often remain multilocular (multiple lipid droplets) and may not fully differentiate to unilocular adipocytes. Further, differentiation capacity of 3T3-L1 cells decreases with increasing number of passages [13]. In addition to other limitations of cell culture technique, results from in vitro studies may not fully reflect in vivo condition due to physiologic responses active in the whole organism. On the other hand, one advantage of this method is that preadipocytes are adherent cell lines and therefore are suitable for studying molecular mechanisms and transcription factors involved in lipolysis process. Also, culture of these cell lines provides an abundant supply of homogeneous cells which make it an appropriate model for screening compounds for their possible lipolytic or antilipolytic effects. Furthermore, newly differentiated fat cells provide a monolayer culture and can be used for studies of long-term regulation of adipocyte functions [14].

2.2. Use of Differentiated Stroma-Vascular Cells. Adipocytes are responsible for only $25 \%$ of the total cell population of fat tissue. Therefore, nonfat cells comprise a significant part of adipose mass. This part is known as stroma-vascular fraction and includes fibroblasts, macrophages, endothelial cells, blood cells, pericytes, preadipocytes, and mesenchymal stem cells [15]. Culture of stroma-vascular cells in adipocyte differentiation medium gives rise to accumulation of lipid droplets in preadipocytes and mesenchymal stem cells [16]. Then, the differentiated adipocytes can be used for lipolysis studies (Figure 1, green pathway). Use of differentiated stroma-vascular cells, in general, has similar advantages and limitations compared to studies on preadipocyte cell lines. Yet, because stroma-vascular fraction contains various cell types, this model may mimic in vivo conditions of fat tissue complexity more closely than method of preadipocyte cell line culture [13]. 


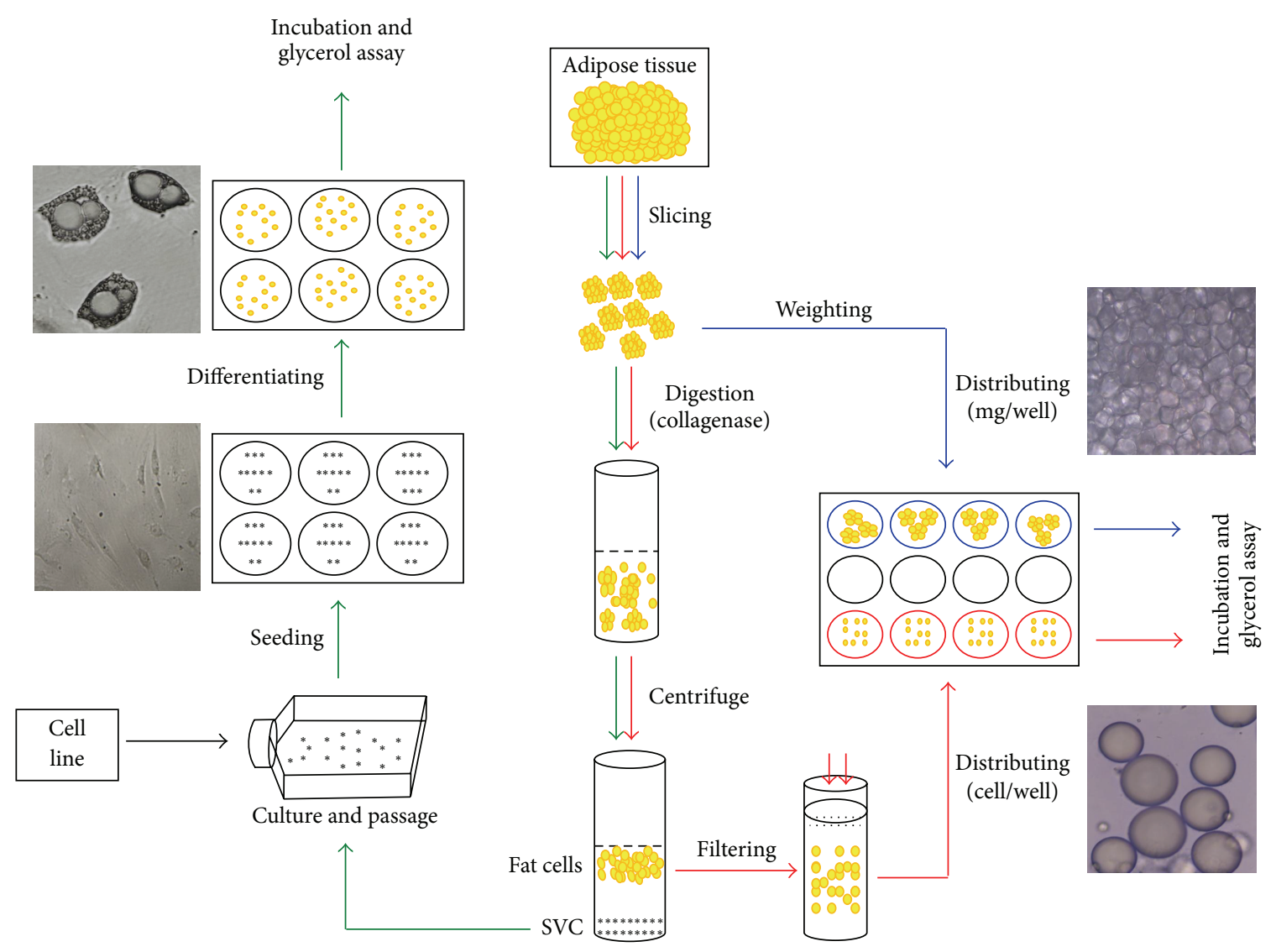

FIGURE 1: Different methods for studying lipolysis. Successive steps for organ culture of adipose tissue, primary culture of adipocytes, and differentiation of stroma-vascular cells (SVC) are shown with blue, red, and green pathways, respectively.

2.3. Primary Culture of Adipocyte. Primary culture of fat cells was first described by Rodbell [17]. In this procedure, samples of adipose tissue removed from human or animals are sliced to small fragments and digested with collagenase. After centrifuging, the floated adipocytes are collected and incubated in the presence of tested compounds in an appropriate buffer, usually Krebs-Ringer bicarbonate buffer (Figure 1, red pathway) [18].

The chief advantage of this method is the ability to study lipolysis in fully differentiated adipocytes [19]. Also, the utility of primary cells provides a rapid technique for testing acute effect of a compound on lipolysis. On the other hand, use of primary adipocytes is limited by their inherent senescence and by interindividual variations [7]. Since crude collagenase may affect cell membrane function, any one series of studies must be done with the same batch of this enzyme [20]. Yet, freshly prepared adipocytes may exhibit a wide day-today range of lipolysis following their isolation. This problem can be ameliorated by adding adenosine deaminase to the medium to negate antilipolytic effect of endogenous adenosine [21]. In addition, long-term culture of isolated adipocytes may be associated with loss of insulin sensitivity and loss of adipocyte-specific gene expression, for example, GLUT4 [22, 23]. Because of several reports on fat depot-related variations in the hormone receptor expression, adipokine secretory profile, adipocyte cell size, glucose uptake, and lipolysis, suitable depot should be selected for adipocyte isolation according to the goal of study [24-28]. For example, it has been reported that subcutaneous adipocytes, relative to intraabdominal adipocytes, are more responsive to antilipolytic action of insulin and less sensitive to lipolytic action of catecholamines [29-31].

2.4. Organ Culture of Adipose Tissue. Organ culture system of adipose tissue was first described by Slavin and Elias [32]. In this method, samples of adipose tissue are sliced into small pieces and distributed into a culture plate containing nutrients and electrolytes (e.g., M199 medium) and maintained in incubator (Figure 1, blue pathway) [33-35]. Although Gesta and coworkers showed that culture of adipose tissue leads to alteration of adipocyte gene expression, several studies demonstrated that adipose tissue can be cultured in vitro with preservation of hormonal responsiveness and maintenance of gene expression up to 2 weeks [36-39]. Lipolysis study can be done on organ cultured tissue itself or on adipocytes isolated from the cultured tissue [40-43].

Organ culture system of adipose tissue preserves extracellular matrix and paracrine interactions between different cell types that can influence adipocyte metabolism. Thus, data obtained from this method have a good correlation with those of in vivo situation and is useful for chronic lipolysis studies. Even, for acute studies, tissues can be culture 
24-48 $\mathrm{h}$ prior to the treatments, allowing the factors to equilibrate with culture medium and therefore to minimize interindividual variability caused by subject factors such as current health status, hormonal status, and medications $[33,34,40]$. The elimination of interindividual variability causes good reproducibility in results. Further, a number of researchers have succeeded in eliciting effects of compounds using organ culture system in cases in which isolated fat cells were unresponsive $[15,19,33,34]$. Nevertheless, with organ culture, it cannot be determined whether lipolytic or antilipolytic effects of compounds added to culture medium induced by direct actions of them on adipocyte itself or mediated by other cell types [19].

In organ culture method, like primary culture of adipocyte, suitable fat depot should be selected for studying lipolysis when considering depot-related variations in adipocyte responsiveness [24-28].

2.5. Microdialysis of Adipose Tissue. Microdialysis technique was introduced over 40 years ago to measure brain neurotransmitters in animal studies. This method was then adapted for adipose tissue to continuous sampling of metabolites (glucose, glycerol, lactate, adenosine, etc.) from extracellular space from animals or human. For adipose tissue microdialysis, especial probes are inserted percutaneously after light intradermal anesthesia into the subcutaneous fat. The probes are connected to a microinjection pump and perfused with Ringer solution supplemented with ethanol (for monitoring local blood flow). For lipolysis evaluation, glycerol concentration in the dialysate is determined and plotted against the perfusion rates $[44,45]$. Although quantitative evaluation of glycerol release is difficult with this technique, it is a powerful method for pharmacological studies of lipolysis when used in a semiquantitative way [46]. Microdialysis permits introduction of exogenous chemicals in fat tissue to investigate the resulting local lipolysis changes without general effects on the body. In addition, this method allows continuous study of local response inside the tissue after systemic administration of chemicals [45]. It is also a promising tool in pharmacokinetic studies of drugs affecting adipose tissue metabolism [47]. One of the major disadvantages of microdialysis techniques is that its application on human is restricted to subcutaneous fat depot and it is difficult to evaluate metabolism of intra-abdominal adipose tissues [46]. Further, microdialysis is time consuming and uncomfortable for the patient and maybe associated with risk of infection. Also, various factors (perfusion rate, composition of the perfusate, size of dialysis membrane's pores, temperature inside and outside the probe, etc.) can impact on microdialysis results and the examiner should be expert in controlling these variables.

\section{Conclusion}

Given the recent increase in attention to study the adipose tissue metabolism, this review was undertaken to compare advantages and limitations of current research methods for studying lipolysis. Several experimental techniques of adipocytes and adipose culture have been described in the litterateur. The techniques are classified into five main categories: culture of preadipocyte cell lines, use of differentiated stroma-vascular cells, primary culture of freshly isolated adipocyte, organ culture of adipose tissue, and microdialysis technique. Use of preadipocyte cell lines, differentiated stroma-vascular cells, or freshly isolated adipocytes provides abundant supply of fat cells which is suitable for screening substances for their lipolytic or antilipolytic activities and for study molecular mechanisms of lipolysis. Therefore, when the possible effect of a substance is tested for the first time, these methods are preferred. Nevertheless, cell lines or isolated cells may not exactly represent the responsiveness and the full spectrum of metabolic characteristics of adipose tissue [8]. On the other hand, organ culture and microdialysis preserve extracellular matrix and paracrine interactions and data obtained from these techniques have good correlation with in vivo studies.

Taken together, this present review provides an initial comparison of different in vitro and in situ methods for studying lipolysis in the hope that chose of appropriate method for a given study aim will be considered.

\section{Acknowledgments}

Salary support was provided by Mashhad University of Medical Sciences and Guilan University of Medical Sciences. The authors have no other relevant affiliations or financial involvement with any other organization.

\section{References}

[1] M. Ahmadian, Y. Wang, and H. S. Sul, "Lipolysis in adipocytes," International Journal of Biochemistry and Cell Biology, vol. 42, no. 5, pp. 555-559, 2010.

[2] V. Large, O. Peroni, D. Letexier, H. Ray, and M. Beylot, "Metabolism of lipids in human white adipocyte," Diabetes and Metabolism, vol. 30, no. 4, pp. 294-309, 2004.

[3] S. Viswandha and C. Londos, "Determination of lipolysis in isolated primary adipocytes," in Adipose Tissue Protocols, K. Yang, Ed., pp. 299-306, Humana Press, Totowa, NJ, USA, 2nd edition, 2008.

[4] P. Arner, "Human fat cell lipolysis: biochemistry, regulation and clinical role," Best Practice and Research, vol. 19, no. 4, pp. 471482, 2005.

[5] G.-Y. Carmen and S.-M. Víctor, "Signalling mechanisms regulating lipolysis," Cellular Signalling, vol. 18, no. 4, pp. 401-408, 2006.

[6] H. Green and O. Kehinde, "An established preadipose cell line and its differentiation in culture. II. Factors affecting the adipose conversion," Cell, vol. 5, no. 1, pp. 19-27, 1975.

[7] E. R. Hugo, T. D. Brandebourg, C. E. S. Comstock, K. S. Gersin, J. J. Sussman, and N. Ben-Jonathan, "LS14: a novel human adipocyte cell line that produces prolactin," Endocrinology, vol. 147, no. 1, pp. 306-313, 2006.

[8] M. Wabitsch, S. Bruderlein, I. Melzner, M. Braun, G. Mechtersheimer, and P. Moller, "LiSa-2, a novel human liposarcoma cell line with a high capacity for terminal adipose differentiation," International Journal of Cancer, vol. 88, pp. 889-894, 2000.

[9] I. Torii, S. Morikawa, A. Nakano, and K. Morikawa, "Establishment of a human preadipose cell line, HPB-AML-I: refractory 
to PPAR $\gamma$-mediated adipogenic stimulation," Journal of Cellular Physiology, vol. 197, no. 1, pp. 42-52, 2003.

[10] R. Li, H. Guan, and K. Yang, "Neuropeptide Y potentiates beta-adrenergic stimulation of lipolysis in 3T3-L1 adipocytes," Regulatory Peptides, vol. 178, pp. 16-20, 2012.

[11] L. Zhou, X. Wang, Y. Yang et al., "Berberine attenuates cAMPinduced lipolysis via reducing the inhibition of phosphodiesterase in 3T3-L1 adipocytes," Biochimica et Biophysica Acta, vol. 1812, no. 4, pp. 527-535, 2011.

[12] X. Guo and K. Liao, "Analysis of gene expression profile during 3T3-L1 preadipocyte differentiation," Gene, vol. 251, no. 1, pp. 45-53, 2000.

[13] S. P. Poulos, M. V. Dodson, and G. J. Hausman, "Cell line models for differentiation: preadipocytes and adipocytes," Experimental Biology and Medicine, vol. 235, no. 10, pp. 1185-1193, 2010.

[14] D. C. Adler-Wailes, E. L. Guiney, N. E. Wolins, and J. A. Yanovski, "Long-term ritonavir exposure increases fatty acid and glycerol recycling in 3T3-L1 adipocytes as compensatory mechanisms for increased triacylglycerol hydrolysis," Endocrinology, vol. 151, no. 5, pp. 2097-2105, 2010.

[15] G. Fruhbeck, "Overview of adipose tissue and its role in obesity and metabolic disorders," in Adipose Tissue Protocols, K. Yang, Ed., pp. 1-22, Humana Press, Totowa, NJ, USA, 2nd edition, 2008.

[16] A. Ghorbani, M. R. Hadjzadeh, Z. Rajaei, and S. B. Zendehbad, "Effects of fenugreek seeds on adipogenesis and lipolysis in normal and diabetic rats," Pakistan Journal of Biological Sciences. In press.

[17] M. Rodbell, "Metabolism of isolated fat cells: effects of hormones on glucose metabolism and lipolysis," The Journal of Biological Chemistry, vol. 239, pp. 375-380, 1964.

[18] J. R. Monzon, R. Basile, S. Heneghan, V. Udupi, and A. Green, "Lipolysis in adipocytes isolated from deep and superficial subcutaneous adipose tissue," Obesity Research, vol. 10, no. 4, pp. 266-269, 2002.

[19] S. K. Fried and N. Moustaid-Moussa, "Culture of adipose tissue and isolated adipocytes," Methods in Molecular Biology, vol. 155, pp. 197-212, 2001.

[20] R. Taylor, "Use of adipose tissue for metabolic studies," Bailliere's Clinical Endocrinology and Metabolism, vol. 1, no. 4, pp. 10231035, 1987.

[21] R. C. Honnor, G. S. Dhillon, and C. Londos, "cAMP-dependent protein kinase and lipolysis in rat adipocytes. I. Cell preparation, manipulation, and predictability in behavior," Journal of Biological Chemistry, vol. 260, no. 28, pp. 15122-15129, 1985.

[22] K. A. Carswell, M.-J. Lee, and S. K. Fried, "Culture of isolated human adipocytes and Isolated adipose tissue," Methods in Molecular Biology, vol. 806, pp. 203-214, 2012.

[23] P. M. Gerrits, A. L. Olson, and J. E. Pessin, "Regulation of the GLUT4/muscle-fat glucose transporter mRNA in adipose tissue of insulin-deficient diabetic rats," Journal of Biological Chemistry, vol. 268, no. 1, pp. 640-644, 1993.

[24] C. T. Montague, J. B. Prins, L. Sanders, J. E. Digby, and S. O'Rahilly, "Depot- and sex-specific differences in human leptin mRNA expression: implications for the control of regional fat distribution," Diabetes, vol. 46, no. 3, pp. 342-347, 1997.

[25] P. Arner, "Differences in lipolysis between human subcutaneous and omental adipose tissues," Annals of Medicine, vol. 27, no. 4, pp. 435-438, 1995.

[26] M. Stolic, A. Russell, L. Hutley et al., "Glucose uptake and insulin action in human adipose tissue-influence of BMI, anatomical depot and body fat distribution," International Journal of Obesity, vol. 26, no. 1, pp. 17-23, 2002.

[27] A. Ghorbani, M. Varedi, and G. R. Omrani, "Effects of aging associated weight gain on the cell size and heterogeneity of different fat depots in the rat," Iranian Journal of Endocrinology \& Metabolism, vol. 11, pp. 713-720, 2009.

[28] A. Ghorbani, M. Varedi, M.-A.-R. Hadjzadeh, and G. H. Omrani, "Type-1 diabetes induces depot-specific alterations in adipocyte diameter and mass of adipose tissues in the rat," Experimental and Clinical Endocrinology and Diabetes, vol. 118, no. 7, pp. 442-448, 2010.

[29] B. Richelsen, S. B. Pedersen, T. Moller-Pedersen, and J. F. Bak, "Regional differences in triglyceride breakdown in human adipose tissue: effects of catecholamines, insulin, and prostaglandin E2," Metabolism, vol. 40, no. 9, pp. 990-996, 1991.

[30] J. R. Zierath, J. N. Livingston, A. Thörne et al., "Regional difference in insulin inhibition of non-esterified fatty acid release from human adipocytes: relation to insulin receptor phosphorylation and intracellular signalling through the insulin receptor substrate-1 pathway," Diabetologia, vol. 41, no. 11, pp. 1343-1354, 1998.

[31] G. Tavernier, J. Galitzky, P. Valet et al., "Molecular mechanisms underlying regional variations of catecholamine- induced lipolysis in rat adipocytes," American Journal of Physiology. Endocrinology and Metabolism, vol. 268, no. 6, pp. E1135-E1142, 1995.

[32] B. G. Slavin and J. J. Elias, “The influence of pituitary hormones and norepinephrine on the size of adipose cells in organ culture," Anatomical Record, vol. 164, no. 2, pp. 141-151, 1969.

[33] A. Ghorbani, G. R. Omrani, M. A. R. Hadjzadeh, and M. Varedi, "Effects of rat C-peptide-II on lipolysis and glucose consumption in cultured rat adipose tissue," Experimental and Clinical Endocrinology and Diabetes, vol. 119, no. 6, pp. 343-347, 2011.

[34] A. Ghorbani, G. H. Omrani, M. R. Hadjzadeh, and M. Varedi, "Proinsulin C-peptide inhibits lipolysis in diabetic rat adipose tissue through phosphodiestrase-3B enzyme," Hormone and Metabolic Research, vol. 45, pp. 221-225, 2013.

[35] B. Alinejad, R. Shafiee-Nick, and A. Ghorbani, "The effect of cilostamide derivatives on lipolysis of rat retroperitoneal adipose tissue," Clinical Biochemistry, vol. 44, p. S248, 2011.

[36] S. Gesta, K. Lolmède, D. Daviaud et al., "Culture of human adipose tissue explants leads to profound alteration of adipocyte gene expression," Hormone and Metabolic Research, vol. 35, no. 3, pp. 158-163, 2003.

[37] U. Smith and B. Jacobsson, "Studies of human adipose tissue in culture. II. Effects of insulin and of medium glucose on lipolysis and cell size," Anatomical Record, vol. 176, no. 2, pp. 181-183, 1973.

[38] R. G. Vernon, R. A. Clegg, and D. J. Flint, "Metabolism of sheep adipose tissue during pregnancy and lactation. Adaptation and regulation," Biochemical Journal, vol. 200, no. 2, pp. 307-314, 1981.

[39] J. P. Robertson, A. Faulkner, and R. G. Vernon, "Regulation of glycolysis and fatty acid synthesis from glucose in sheep adipose tissue," Biochemical Journal, vol. 206, no. 3, pp. 577-586, 1982.

[40] M. Cifuentes, C. Albala, and C. V. Rojas, "Differences in lipogenesis and lipolysis in obese and non-obese adult human adipocytes," Biological Research, vol. 41, no. 2, pp. 197-204, 2008.

[41] D. Newby, A. Gertler, and R. G. Vernon, "Effects of recombinant ovine leptin on in vitro lipolysis and lipogenesis in subcutaneous 
adipose tissue from lactating and nonlactating sheep," Journal of Animal Science, vol. 79, no. 2, pp. 445-452, 2001.

[42] M. Ottosson, P. Lönnroth, P. Björntorp, and S. Edèn, "Effects of cortisol and growth hormone on lipolysis in human adipose tissue," Journal of Clinical Endocrinology and Metabolism, vol. 85, no. 2, pp. 799-803, 2000.

[43] Y. Wang, S. K. Fried, R. N. Petersen, and P. A. Schoknecht, "Somatotropin regulates adipose tissue metabolism in neonatal swine," Journal of Nutrition, vol. 129, no. 1, pp. 139-145, 1999.

[44] P. Arner and J. Bolinder, "Microdialysis of adipose tissue," Journal of Internal Medicine, vol. 230, no. 4, pp. 381-386, 1991.

[45] P. Barbe, C. Darimont, P. Saint-Marc, and J. Galitzky, "Measurements of white adipose tissue metabolism by microdialysis technique," Methods in Molecular Biology, vol. 155, pp. 305-321, 2001.

[46] K. N. Frayn, B. A. Fielding, and L. K. M. Summers, "Investigation of human adipose tissue metabolism in vivo," Journal of Endocrinology, vol. 155, no. 2, pp. 187-189, 1997.

[47] T. Zornoza, M. J. Cano-Cebrian, A. Polache, and L. Granero, "Quantitative in vivo microdialysis in pharmacokinetic studies," Microdialysis Techniques in Neuroscience, vol. 75, pp. 103-120, 2013. 


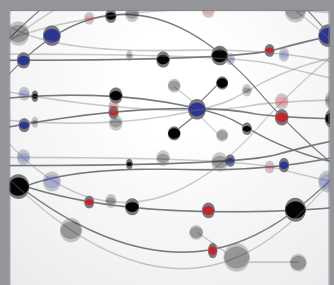

The Scientific World Journal
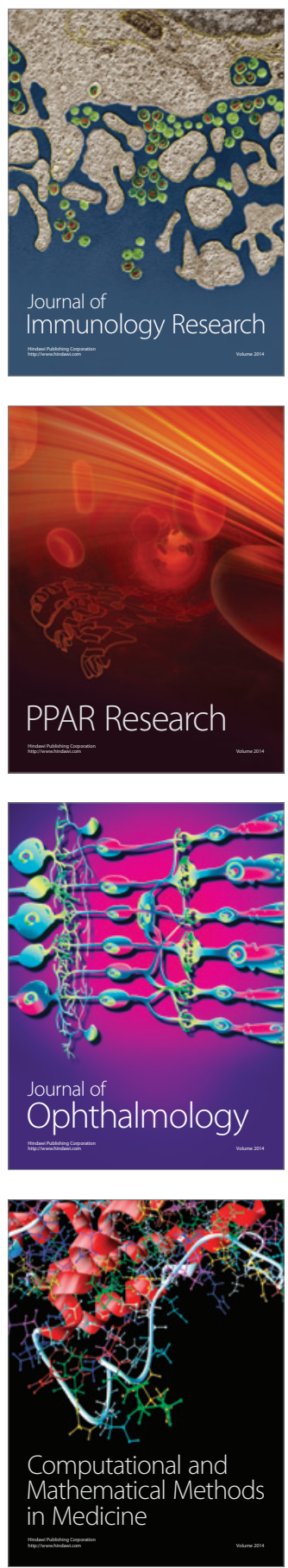

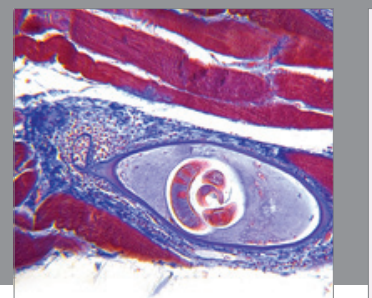

Gastroenterology

Research and Practice
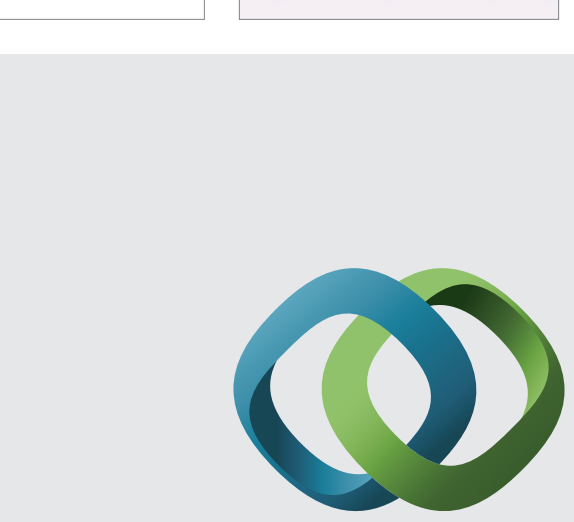

\section{Hindawi}

Submit your manuscripts at

http://www.hindawi.com
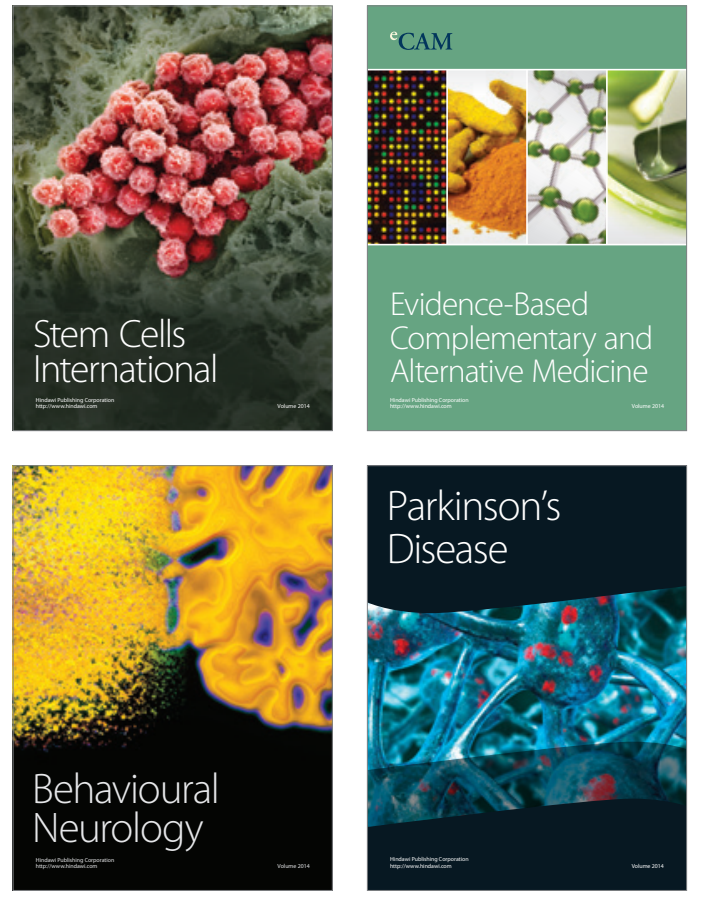
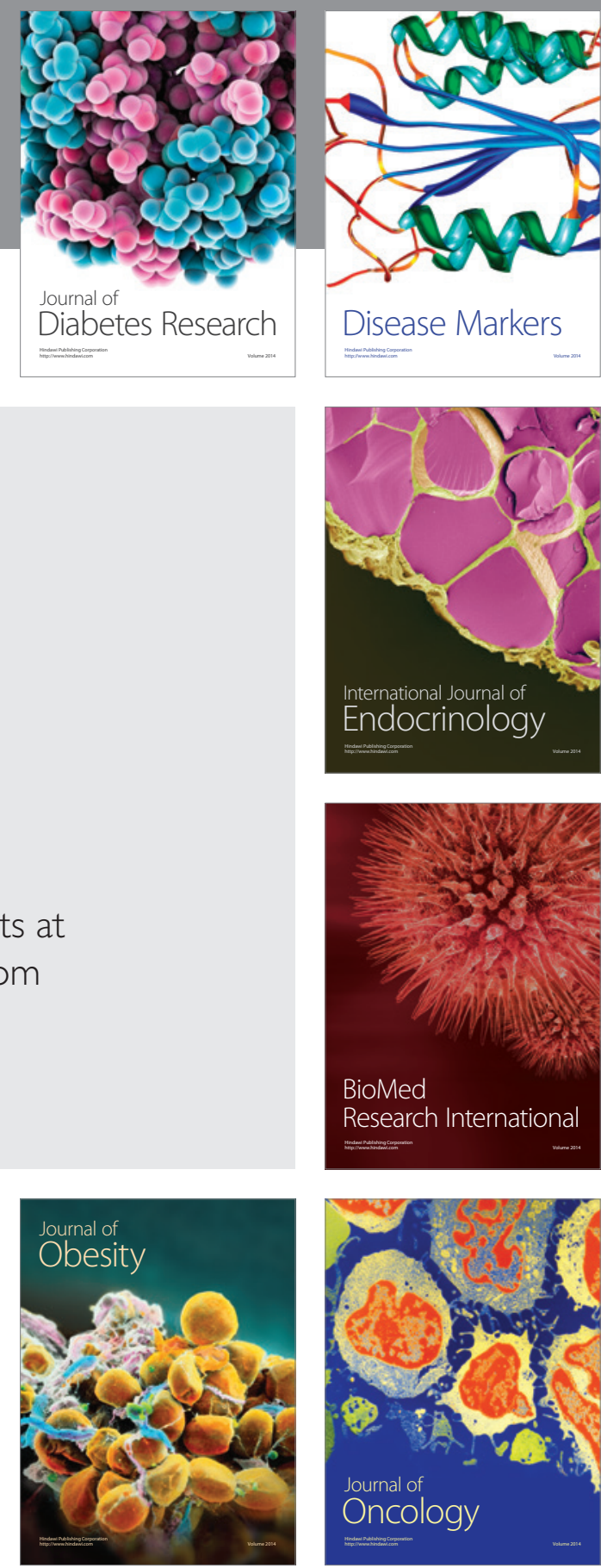

Disease Markers
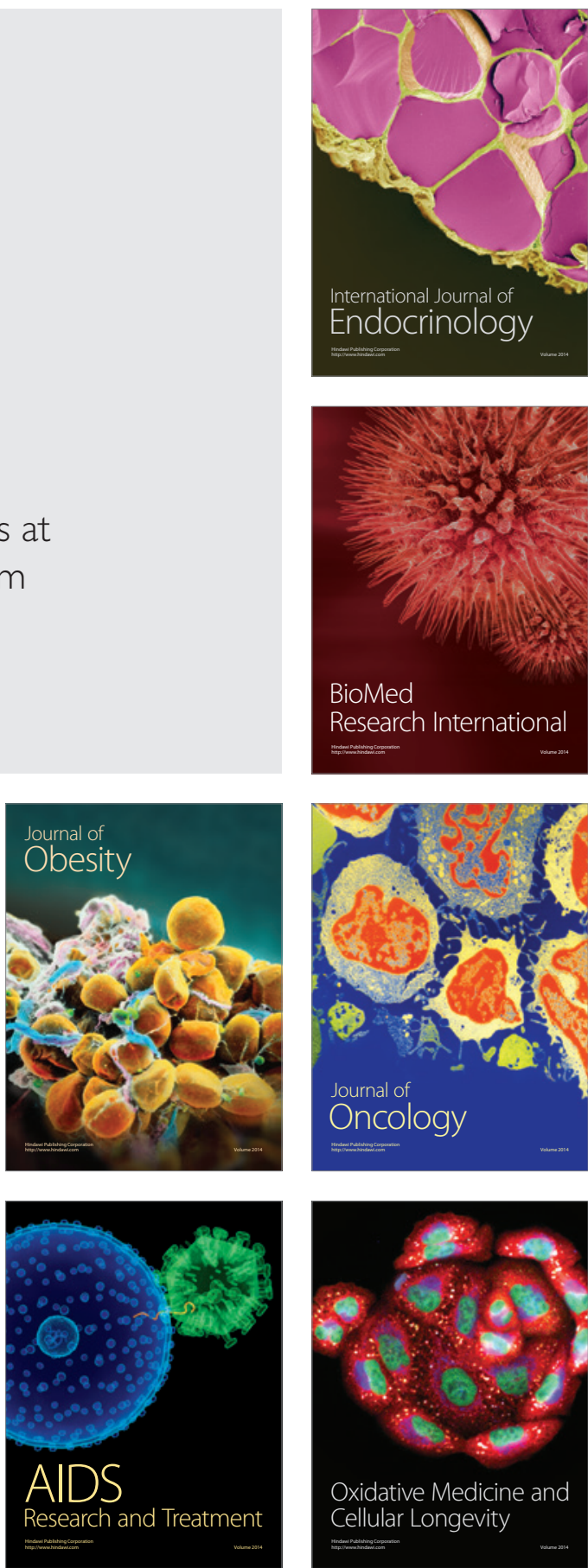